\title{
Effect of Acidified Drinking Water by Organic Acids on Broiler Performance and Gut Health
}

\begin{abstract}
Asmaa Metwally Ali ${ }^{1}$, Hassan Mostafa El Agrabi ${ }^{1}$ Mohamed Mamdouh Hamoud 2 , Abdelrhman Mohamed Gamal ${ }^{1}$, Mohamed Refat Mousa ${ }^{3}$, Shimaa Abo Elsoud Nasr ${ }^{1}$, Mohamed Ahmed Hassan El Shater ${ }^{4}$, Samah Elsaeed Laban ${ }^{1}$, Osama Kamel Zahran ${ }^{1}$, Mohamed Mohamed Ali ${ }^{1 *}$
\end{abstract}

${ }^{1}$ Department of Animal Hygiene and Veterinary Management, Faculty of Veterinary Medicine, Cairo University, Giza, 12211, Egypt; ${ }^{2}$ Departement of Poultry and Rabbit Disease Faculty of Veterinary Medicine Cairo University, Giza 12211, Egypt; ${ }^{3}$ Department of Pathology, Faculty of Veterinary Medicine, Cairo University, Giza,12211, Egypt; ${ }^{4}$ Food Hygiene Unit, Animal Health Research Institute, Dokki, Giza, Egypt.

\begin{abstract}
The usage of organic acids (OAs) in poultry industry as an alternative to antibiotic growth promoters has been functioning since 2006 The aim of the current study is to evaluate the effect of prolonged usage of single or mixture of different OAs to acidify the drinking water and monitor their effect on the broiler growth performance, water consumption, feed conversion and intestinal histomorphology. A total of 450 commercial broiler chicks (Arbor acres breed) were randomly divided into nine main groups (50 birds/each). Our results revealed that during the entire growth period, the water was supplemented with acidified water with a $\mathrm{pH}$ range between 2.7- 3.7 that showed best performance results. All broilers which given acidified water showed significant improvement in final body weight $(\mathrm{P}$ $\leq 0.05$ ), feed conversion ratio (FCR) and villus high: crypt depth ratio ( $\mathrm{V}: \mathrm{C}$ ratio) for the intestinal mucosa compared to non-treated control group (negative control). On the other hand, broiler chicks that supplied with acidified water including formic acid $(\mathrm{pH} 2.5)$ revealed significant reduction in all tested parameters $(\mathrm{P} \leq 0.05)$ however, water consumption was not affected by lowering the $\mathrm{pH}$ in all groups. In conclusions, our findings showed that continuous supplementation of both single and mixture of organic acids can improve the broiler growth performance.
\end{abstract}

Keywords | Organic acids, Acidified water, Single and mixture organic acid, Broiler performance, Intestinal mucosa

\author{
Received | August 09, 2020; Accepted | September 03, 2020; Published | November 15, 2020 \\ *Correspondence | M.M. Ali, Department of Animal Hygiene and Veterinary Management, Faculty of Veterinary Medicine, Cairo University, Giza, 12211, \\ Egypt; Email: M.Aly24861@gmail.com, m.Khadrawy17@yahoo.com \\ Citation | Ali AM, Elagrb HM, Hamoud MM, Gamal AM, Mousa MR, Nasr SAE, ElShater MAH, Laban SF, Zahran OK, Ali MM (2020). Effect of acidified \\ drinking water by organic acids on broiler performance and gut health. Adv. Anim. Vet. Sci. 8(12): 1301-1309. \\ DOI | http://dx.doi.org/10.17582/journal.aavs/2020/8.12.1301.1309 \\ ISSN (Online) | 2307-8316; ISSN (Print) | 2309-3331
}

Copyright $\odot 2020$ Ali et al. This is an open access article distributed under the Creative Commons Attribution License, which permits unrestricted use, distribution, and reproduction in any medium, provided the original work is properly cited.

\section{INTRODUCTION}

$\mathrm{T}$ here is an interest to investigate the growth promoting products rather than antibiotics since their usage in animal's food have been associated with great health hazards and resistance (Roy et al., 2002). Therefore, intensive poultry industry search to minimize the microbial load associated to farms environment and final products. Broiler performance and feed conversion efficiency are closely related with the amount and type of gut microbial load, the morphological structure of the intestinal wall and the immune system response (Huyghebaert et al., 2011).
Meanwhile, safe, non-therapeutic, and antimicrobial product like Organic Acid (OA) can be added to drinking water (acidifier) to achieve the optimum broiler performance (Araujo et al., 2019) and improving the water quality (Krug et al., 2012). It is well known that contaminated drinking water is a risk factor which enhance the multiplication and spreading of water borne pathogens in broiler farms (Chaveerach et al., 2004).

Likewise, previous studies showed that broilers supplemented with organic acids in drinking water have intact and highest intestinal villi with deep crypt depth 
(Eftekhari et al., 2015) which maximize more nutrient absorption, retention of protein, and dry mater leading to improvement in final Body weight and feed conversion ratio (FCR).

Generally, most acidifiers/organic acids (OAs) used in the poultry sector are weak, short chain (C1-C7) fatty acids and highly soluble in water with antimicrobial properties (Khan and Iqbal, 2015). Among most organic acids the lactic acid, formic acid, citric acid, propionic acid is commonly used. It was thought that acidifiers are composed of a single acid, but a combination of two or more have more synergistic microbial effect (Šamudovská et al., 2018).

For example, using formic acid, either individually or mixed with propionic acid in broiler drinking water increases the body weight gain, nitrogen retention and improves the FCR (Desai et al., 2007). Several studies have been reported that broiler drinking water supplementation with citric acid can increase the body weight gain, mineral retention, improve feed efficacy and immune response (Kopecký et al., 2012). Also, drinking water can be acidified with mixture of citric acid and acetic acid achieved significant increase in body weight as a result of improving the intestinal morphology (Abdelrazek et al., 2016). Recently, commercial organic acids combination (lactic, formic, citric and propionic acids) has been improved the broiler flock uniformity and body weight gain (Eftekhari et al., 2015).

Therefore, it is very critical to investigate the effect of continuous addition of OAs in drinking water of broiler due to lack of data relating to the usage of OAs either single or mixture in broiler industry. Thus, the aim of the current study is to determine the effects of continuous addition of either single or mixture of OAs in the drinking water during the whole rearing period ( 12 hours per day interval) with monitoring the body weight FCR, the water consumption rate, and the intestinal morphology of broiler chicken. This study will help us to conclude the most suitable OAs (single or mixture) to be used for broiler leading to achieving the maximum performance.

\section{MATERIALS AND METHODS}

\section{Animal ethics}

All experiments were carried out at the Department of Veterinary Hygiene and Management, Faculty of Veterinary Medicine, Cairo University. The Institutional Animal Care and Use Committee, Cairo University (CUIACUC) approved the experiment protocol with approval number CU II F 2019.

\section{Birds AND MANAGEMENT}

A total of 450 one-day-old unsexed broiler chicks (Arbor
Acre breed) were used along 35 days growing trial period in the current experiment. The average initial body weight of chicks was 42 grams and were housed in a good ventilated clean room. The floor area forming a stocking ratio ten bird /one meter at the age of slaughter. The floor bedded by wood shavings as litter material forming a deep litter of seven $\mathrm{cm}$ depth. Adequate number of feeders and drinkers were provided to each compartment and the temperature adjusted according to chicks age. The light was provided to chicks according to (Aviagen, 2018) 23 hours light and 1 hour dark up to 7 days of age, then around 20 hours light and 4 hours darkness.

On the day of chick's arrival, they were provided with ground starter ration, water-soluble vitamins and electrolytes were added to the drinking water for the first 3days. After 24 hours, crop test was applied to ensure good vitality and feeding behavior.

Poultry feed was provided by Cairo poultry company ${ }^{\circledR}$; starter ration $(23 \%$ protein, $3000 \mathrm{kcal})$ till 10 days old (weighting about 300 gram), then grower ration (21\% protein, $3100 \mathrm{kcal}$ ) till 25 days old (weighting about $1 \mathrm{Kg}$ ) and finally finishing ration $(18.5 \%$ protein, $3200 \mathrm{kcal})$ till the end of experiment. Feed was continuously offered ad libitum daily as well as monitoring the water consumption throughout the trial period. No antibiotics, growth promoters or feed enzymes were included in the water or basal diets through the whole experiment.

\section{EXPERIMENTAL DESIGN}

The used organic acids in the current study are described in Table 1. Chicks were provided with normal drinking water for the first week, and then were randomly divided into nine groups (50 chicks/each) on day 7 old (Figure 1 ). Chicks in the treated groups supplemented with OAs were divided as follow; 1) Single organic acid treated groups that consumed acidified drinking water administrated continuously for 12 hours per day till the end of the experiment at concentration of 1\%; group 1 (Formic acid 1\%), group 2 (Lactic acid 1\%), group 3 (Propionic acid 1\%), and group 4 (Citric acid 1\%), 2) organic acid mixture $(\mathrm{OAB})$ treated groups that received four OAs, prepared with equal ratio (0.3:0.3:0.3), and administrated continuously for 12 hours per day till the end of the experimental trial, group 5 (mixture 1 = Formic+ Lactic+ Propionic (, group 6 (mixture 2 = Formic + Lactic + Citric), group 7 (mixture 3 = Formic+ Propionic+ Citric), group 8 (mixture 4 = Lactic+ Propionic+ Citric). While the negative control non-treated group $(\mathrm{Gr} 9)$ received normal drinking water $(\mathrm{pH}$ 7.6) during whole experiment.

The Schedule of chicks' vaccination program as mentioned in Table 2. 
Table 1: Organic acids used in the experiment.

\begin{tabular}{llll} 
Organic acids & Chemical formula & Concentration & Manufacture \\
Formic acid & $\mathrm{HCOOH}$ & $99 \%$ & Alpha Chemicals ${ }^{\circledR}$ \\
\hline Lactic acid & $\mathrm{CH} 3 \mathrm{CH} \mathrm{OH} \mathrm{COOH}$ & $95 \%$ & Alpha Chemicals $^{\circledR}$ \\
\hline Propionic acid & $\mathrm{CH}_{3} \mathrm{CH}_{2} \mathrm{COOH}$ & $99 \%$ & Sigma ALDRICH \\
\hline Citric acid monohydrate & $\mathrm{COOH} \mathrm{CH} 2 \mathrm{C}(\mathrm{OH})(\mathrm{COOH}) \mathrm{CH} 2 \mathrm{COOH}$ & $99.5 \%$ & AVI-CHEM ${ }^{\circledR}$ laboratories, India
\end{tabular}

Table 2: The Schedule of chicks'vaccination program.

\begin{tabular}{|c|c|c|c|}
\hline Age of vaccination & Vaccination aganist & Vaccine & Method of vaccination \\
\hline At 0-day old (on hatchery) & Newcastle viral disease and gumboro disease & Innovac ND-IBD vaccine ${ }^{\circledR}$ & $\mathrm{SC}$ \\
\hline At 3 day old & $\begin{array}{l}\text { Newcastle and infectious bronchitis viral } \\
\text { diseases }\end{array}$ & Clone $30 \mathrm{MA} 5^{\circ}$ and $\operatorname{Var} 2^{\circledR}$ & eye drop \\
\hline At 11 day old & H5 & ME FluVac $\mathrm{H} 5^{\circ}$ & injection \\
\hline
\end{tabular}

Table 3: Effect of added 1\% single organic acids on growth performance in broilers during 35 days of experiment.

\begin{tabular}{|c|c|c|c|c|c|c|c|c|c|c|c|c|}
\hline \multirow{2}{*}{$\begin{array}{l}\text { Treatment } \\
\text { (1\%) }\end{array}$} & \multicolumn{4}{|c|}{ Weight gain (g) } & \multicolumn{4}{|c|}{ Cumulative feed intake (g) } & \multicolumn{4}{|c|}{$\operatorname{FCR}(g / g)$} \\
\hline & 7 days & 18 days & 25 days & 35 days & $\begin{array}{l}7 \\
\text { days }\end{array}$ & $\begin{array}{l}18 \\
\text { days }\end{array}$ & 25 days & $\begin{array}{l}35 \\
\text { days }\end{array}$ & $\begin{array}{l}7 \\
\text { days }\end{array}$ & $\begin{array}{l}18 \\
\text { days }\end{array}$ & $\begin{array}{l}25 \\
\text { days }\end{array}$ & $\begin{array}{l}35 \\
\text { days }\end{array}$ \\
\hline Formic acid & $182 \pm 0.01$ & $641 \pm 0.01^{\mathrm{a}}$ & $1300 \pm 0.01^{a}$ & $2133 \pm 0.04^{a}$ & 200 & 940 & 1890 & 3531 & 1.09 & 1.46 & 1.45 & 1.65 \\
\hline Lactic acid & $182 \pm 0.01$ & $704 \pm 0.01^{\mathrm{ab}}$ & $1352 \pm 0.02^{\mathrm{ab}}$ & $2485 \pm 0.02^{\mathrm{bc}}$ & 200 & 940 & 1890 & 3531 & 1.09 & 1.33 & 1.39 & 1.42 \\
\hline Propionic acid & $182 \pm 0.01$ & $700 \pm 0.01^{\mathrm{ab}}$ & $1358 \pm 0.02^{\mathrm{ab}}$ & $2537 \pm 0.01^{\mathrm{c}}$ & 200 & 940 & 1890 & 3585 & 1.09 & 1.34 & 1.39 & 1.41 \\
\hline Citric acid & $182 \pm 0.01$ & $735 \pm 0.01^{b}$ & $1422 \pm 0.02^{b}$ & $2513 \pm 0.01^{\mathrm{c}}$ & 200 & 940 & 1919 & 3540 & 1.09 & 1.27 & 1.34 & 1.40 \\
\hline Control & $182 \pm 0.01$ & $708 \pm 0.01^{b}$ & $1395 \pm 0.02^{b}$ & $2363 \pm 0.04^{b}$ & 200 & 940 & 1899 & 3583 & 1.09 & 1.32 & 1.36 & 1.51 \\
\hline$P$-value & -- & 0.002 & 0.002 & $<0.0001$ & -- & -- & -- & -- & -- & -- & -- & -- \\
\hline
\end{tabular}

a,b,c Different superscripts within the same column indicate significant difference at $(P<0.05)$; Data was expressed as Mean $\pm \mathrm{SE}$ (standard error); FCR: Feed conversion ratio.


Figure 1: Experimental design. 
No other vaccinations are administrated till the end of experiment. Strict biosecurity and hygienic measures have been applied.

\section{EVALUATION PARAMETERS}

\section{GROWTH PERFORMANCE}

At day 7 old, the body weight was recorded before administration of the organic acids. Then, body weight (B.Wt.), feed intake, and feed conversion ratio (FCR) were recorded on day 7, 18, 25, and 35 old. Likewise, treated water consumption was calculated daily.

\section{INTESTINAL HISTOPATHOLOGY AND HISTOMORPHOMETRY}

At the end of the experimental trial, five birds from each group were slaughtered to examine the intestinal morphology. Briefly, $5 \mathrm{~cm}$ segment from the middle part of the duodenum was dissected out and kept in $10 \%$ neutral buffered formalin. After fixation, the tissue samples were processed, embedded in paraffin and stained by Hematoxylin and Eosin ( $\mathrm{H}$ and $\mathrm{E}$ ) (Bancroft and Gamble, 2008) The villus height $(\mu \mathrm{m})$ was measured from the villus tip to the villus crypt junction, while crypt depth $(\mu \mathrm{m})$ was measured as the distance between the basement membrane and the mouth of crypt (Shokryazdan et al., 2017) using ImageJ software (NIH, USA) and villi to crypt ratio (V:C) was calculated. Twenty measurements were recorded from each sample.

\section{STATISTICAL ANALYSIS}

Data were expressed as means $\pm \mathrm{SE}$, data were analyzed using one-way ANOVA procedure of SPSS 25 program, Post Hock test (Tukey test) used for multi-comparison between raw means. Significance was considered if $\mathrm{P} \leq$ 0.05. Graphs were made using Microsoft office Excel.

\section{RESULTS AND DISCUSSION}

\section{GROWTH PERFORMANCE}

The effect of single OA on the growth performance was summarized in Table 3. At the end of the experiment, there was a significant effect of adding OA in broiler drinking water on the final body weight of all treated groups $(\mathrm{P}<0.0001)$ compared to negative control group. On the other hand, treated group with $1 \%$ formic acid showed significant reduction in performance compared to negative control group $(\mathrm{P}<0.0001)$. Interestingly, the feed consumption rate was not affected by OAs supplementation

Data presented in Table 4 described the effect of water supplementation by OA mixture on growth performance. At the end of experiment, all OA mixtures have significant effect on final body weight $(\mathrm{P}<0.0001)$ compared to nontreated group and the feed consumption was not affected.

\section{WATER CONSUMPTION}

The effect of acidified water due to addition of single OA and $\mathrm{OA}$ mixture on the amount of water consumption was summarized in Tables 5 and 6. At the end of the experiment, all treated groups exhibited non-significant difference $(\mathrm{P}=0.369$ for single acid treatment groups and $\mathrm{P}=0.841$ for $\mathrm{OA}$ mixture treatment groups) compared with negative control group that revealed nearly the equal water consumption.

\section{Histopathology AND Histomorphometry OF INTESTINE}

The photomicrograph of duodenal villi and crypt for chick's groups supplemented with single OA representative photomicrograph of duodenal villi and crypt of single OA groups was shown in Figure 2. Microscopic examination for the duodenum revealed long well-oriented villi and crypts of variable depth. The effect of single OA supplementation on $\mathrm{V}: \mathrm{C}$ ratio is presented in Figure 3; that was nonsignificant difference in formic acid and citric acid groups compared to negative control group $(\mathrm{P} \leq 0.05)$. Meanwhile, the highest significant ratio $(\mathrm{P} \leq 0.05)$ was recorded in lactic acid and propionic acid treated group.

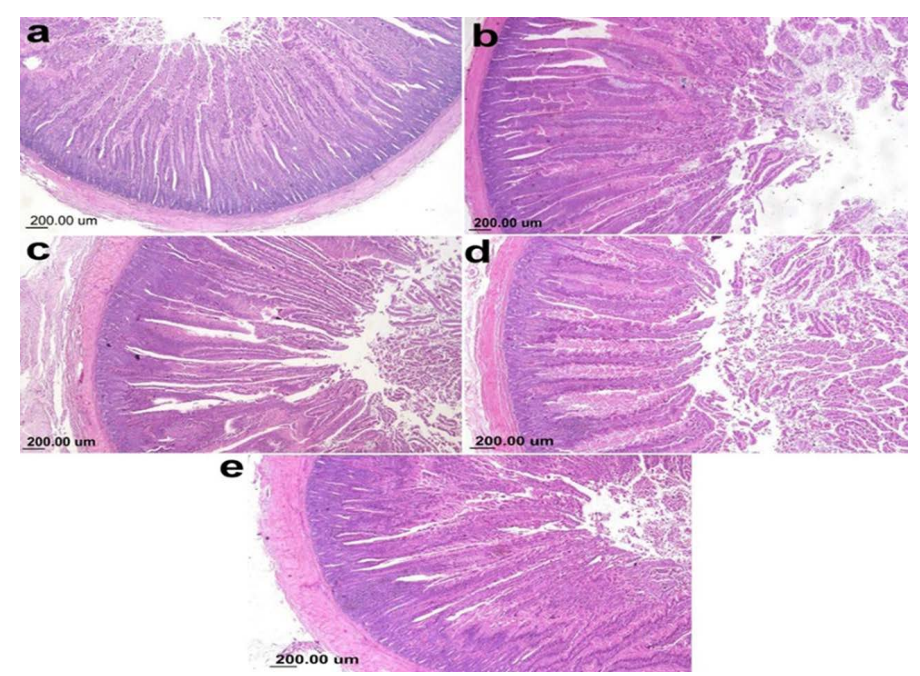

Figure 2: Photomicrograph showing duodenum of broiler chicken supplemented single OA (a) Gr.1 (Formic acid), (b) Gr. 2 (Lactic acid), (c) Gr. 3 (propionic acid), (d) Gr. 4 (Citric acid), (e) Gr. 9 (control group).

On the other hand, the photomicrograph of duodenal villi and crypt of OA mixture treated groups were shown in Figure 4. Microscopic examination of duodenum revealed long well-oriented villi and crypts of variable depth. The effect of OA mixture supplementation on $\mathrm{V}: \mathrm{C}$ ratio presented in Figure 5. Our results revealed non-significant difference $(\mathrm{P} \leq 0.05)$ in (lactic+ formic+ citric) and (formic +citric+ propionic) compared to negative control group. While the highest significant $(\mathrm{P} \leq 0.05)$ was reported in (formic + propionic + citric) and (lactic + formic + propionic) treated groups. 
Table 4: Effect of added 1\% mixture of organic acids (mixture of equal ratio to make $1 \%$ concentration) on growth performance in broilers during 35 days of experiment.

\begin{tabular}{|c|c|c|c|c|c|c|c|c|c|c|c|c|}
\hline \multirow{2}{*}{$\begin{array}{l}\text { Mixture treat- } \\
\text { ments (1\%) }\end{array}$} & \multicolumn{4}{|c|}{ Weight gain (g) } & \multicolumn{4}{|c|}{ Cumulative feed intake (g) } & \multicolumn{4}{|c|}{$\operatorname{FCR}(g / g)$} \\
\hline & 7 days & 18 days & 25 days & 35 days & 7 days & 18 days & 25 days & 35 days & 7 days & 18 days & 25 days & 35 days \\
\hline Mixture 1 & $182 \pm 0.01$ & $762 \pm 0.09^{\mathrm{bc}}$ & $1416 \pm 0.01^{\mathrm{ab}}$ & $2536 \pm 0.0^{2 b}$ & 200 & 940 & 1899 & 3565 & 1.09 & 1.23 & 1.34 & 1.40 \\
\hline Mixture 2 & $182 \pm 0.01$ & $714 \pm 0.01^{\mathrm{ab}}$ & $1362 \pm 0.02^{\mathrm{a}}$ & $2523 \pm 0.0^{3 \mathrm{~b}}$ & 200 & 940 & 1880 & 3480 & 1.09 & 1.31 & 1.38 & 1.3 \\
\hline Mixture 3 & $182 \pm 0.01$ & $739 \pm 0.01^{\mathrm{abc}}$ & $1443 \pm 0.02^{\mathrm{ab}}$ & $2566 \pm 0.0^{2 b}$ & 200 & 940 & 1880 & 3512 & 1.09 & 1.27 & 1.30 & 1.36 \\
\hline Mixture 4 & $182 \pm 0.01$ & $770 \pm 0.01^{c}$ & $1447 \pm 0.02^{b}$ & $2484 \pm 0.0^{2 \mathrm{~b}}$ & 200 & 940 & 1899 & 3565 & 1.09 & 1.22 & 1.31 & 1.43 \\
\hline Control & $182 \pm 0.01$ & $708 \pm 0.01^{a}$ & $1395 \pm 0.02^{\mathrm{ab}}$ & $2363 \pm 0.04^{a}$ & 200 & 940 & 1899 & 3583 & 1.09 & 1.32 & 1.36 & 1.51 \\
\hline $\mathrm{P}$-value & -- & 0.002 & 0.032 & $<0.0001$ & -- & -- & -- & -- & -- & -- & -- & -- \\
\hline
\end{tabular}

a,b,c Different superscripts within the same column indicate significant difference at $(P<0.05)$; Data was expressed as Mean $\pm \mathrm{SE}$ (standard error); FCR: Feed conversion ratio; mixture 1: Formic, lactic, and propionic acids; mixture 2: Formic, lactic, and citric acids; mixture 3: Formic, propionic, and citric acids; mixture 4: Lactic, propionic, and citric acids.

Table 5: Effect of $1 \%$ single organic acid supplementation for 12 hours per day (period of treatment) on water consumption level (Mean Liters $\pm \mathrm{SE})$.

\begin{tabular}{llllll} 
Groups & 1\% Organic acids & Water pH & \multicolumn{2}{c}{ Water consumption (Mean Liters \pm SE) } \\
& & & $\mathbf{7 - 1 4}$ day & $\mathbf{1 5 - 2 2}$ day & 23-35 day \\
Gr 1 & Formic acid & 2.5 & $0.9375 \pm 0.10^{\mathrm{a}}$ & $2.3750 \pm 0.22^{\mathrm{a}}$ & $6.7833 \pm 0.39^{\mathrm{a}}$ \\
\hline Gr 2 & Lactic acid & 2.74 & $2.2813 \pm 0.08^{\mathrm{b}}$ & $3.3125 \pm 0.22^{\mathrm{b}}$ & $7.4000 \pm 0.31^{\mathrm{a}}$ \\
Gr 3 & Propionic acid & 3.23 & $1.3875 \pm 0.21^{\mathrm{a}}$ & $3.4625 \pm 0.19^{\mathrm{b}}$ & $7.3750 \pm 0.33^{\mathrm{a}}$ \\
Gr 4 & Citric acid & 3.7 & $2.3313 \pm 0.09^{\mathrm{b}}$ & $3.2625 \pm 0.21^{\mathrm{b}}$ & $7.6750 \pm 0.30^{\mathrm{a}}$ \\
Gr 9 & Control & 7.6 & $2.2500 \pm 0.06^{\mathrm{b}}$ & $2.9375 \pm 0.19^{\mathrm{ab}}$ & $7.5833 \pm 0.30^{\mathrm{a}}$ \\
& P-value & & $<0.0001$ & 0.007 & 0.369
\end{tabular}

a,b Different superscripts within the same column indicate significant difference at $(P<0.05)$; Data was expressed as Mean $\pm \mathrm{SE}$ (standard error).

Table 6: Effect of $1 \%$ organic acid mixtures supplementation for 12 hours per day (period of treatment) on water consumption level (Mean Liters $\pm \mathrm{SE}$ ).

\begin{tabular}{|c|c|c|c|c|c|}
\hline \multirow[t]{2}{*}{ Groups } & \multirow{2}{*}{$\begin{array}{l}1 \% \text { Organic acids } \\
\text { blend }\end{array}$} & \multirow[t]{2}{*}{ Water $\mathbf{p H}$} & \multicolumn{3}{|c|}{ Water consumption (Mean Liters $\pm \mathrm{SE}$ ) } \\
\hline & & & 7-14 day & 15-22 day & 23-35 day \\
\hline Gr 5 & Mixture 1 & 3.55 & $1.4250 \pm 0.17 \mathrm{ab}$ & $3.2750 \pm 0.23^{\mathrm{ab}}$ & $7.6500 \pm 0.26^{a}$ \\
\hline Gr 6 & Mixture 2 & 3.5 & $1.5625 \pm 0.26^{\mathrm{ab}}$ & $3.0625 \pm 0.27^{\mathrm{ab}}$ & $7.6083 \pm 0.30^{a}$ \\
\hline Gr 7 & Mixture 3 & 3.7 & $1.3875 \pm 0.24^{a}$ & $3.2125 \pm 0.26^{\mathrm{a}}$ & $7.3000 \pm 0.30^{\mathrm{a}}$ \\
\hline Gr 8 & Mixture 4 & 3.6 & $1.8500 \pm 0.21^{\mathrm{ab}}$ & $3.4125 \pm 0.23^{\mathrm{ab}}$ & $7.7583 \pm 0.24^{2}$ \\
\hline \multirow[t]{2}{*}{ Gr 9} & Control & 7.6 & $2.2500 \pm 0.06^{b}$ & $2.9375 \pm 0.19^{b}$ & $7.5833 \pm 0.30^{2}$ \\
\hline & $\mathrm{P}$-value & & 0.030 & 0.030 & 0.841 \\
\hline
\end{tabular}

${ }^{b}$ Different superscripts within the same column indicate significant difference at $(P<0.05)$; Data was expressed as Mean $\pm \mathrm{SE}$ (standard error); mixture 1: Formic, lactic, and propionic acids; mixture 2: Formic, lactic, and citric acids; mixture 3: Formic, propionic, and citric acids; mixture 4: Lactic, propionic, and citric acids.

Acidified water can lower the $\mathrm{pH}$ of all gastrointestinal tract of broiler which enhance the proliferation of beneficial bacterial and reduce the colonization of enteric pathogens (Van Bunnik et al., 2012). Supplementation of OAs can improve the digestion and absorption of nutrients (Hamid et al.,2018), increase mineral retention as phosphorus, tibia ash and toe ash (Nourmohammadi et al., 2012), regulate fat metabolism (Hossain and Nargis, 2016), thereby increase the musculature and reducing abdominal and skin fat. Using single organic acid (propionic acid 1\%) as water acidifier $(\mathrm{pH} 3.23)$ results in significant $(\mathrm{P}=0.015)$ increase in the final body weight $(2537 \mathrm{~g})$ with low FCR (1.41) compared to negative control group. These findings are in agreement with (Khan and Nagra, 2010), they found that dietary supplementation of single propionic acid 0.4 $\%$ can improve the feed intake and body weight only at finisher phase. In contrast (Venkatasubramani et al., 2014), reported non-significant differences in the body weight 
while using low concentration of propionic acid ( 0.1 or $0.15 \%$ ) for 6 week in broiler diet. Our results were supported by histopathological examination of the intestinal villi of treated group with propionic acid which represent the highest integrated villi with highest $\mathrm{V}: \mathrm{C}$ ratio which correlated with increasing the digestion and absorption rate (Montagne et al., 2003). These results explain the high absorption level of nutrient that resulted in increasing the body weight and improvement in the FCR for propionic acid treated group which is in accordance with (Paul et al., 2007) who concluded that long villi of all intestinal segment in broiler feed with propionate salt could improve the digestion and absorption of nutrients.

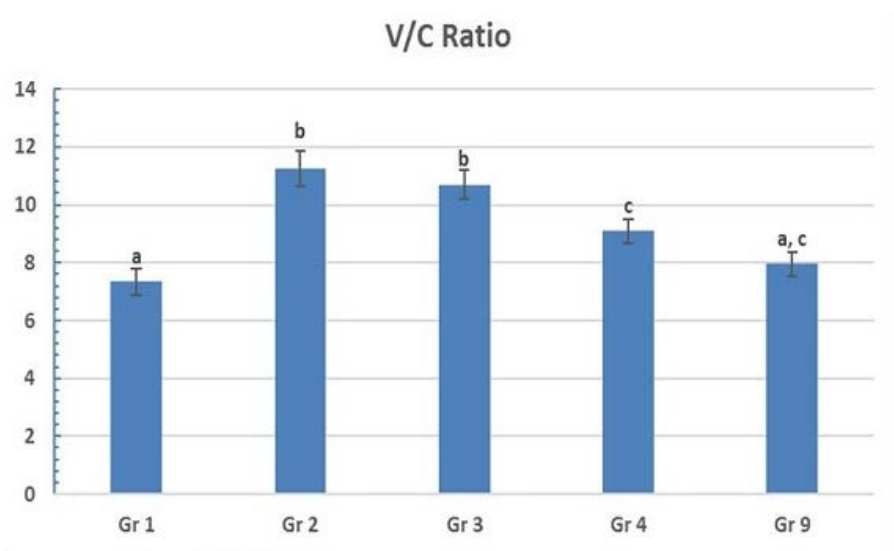

ata was expressed as means $\pm \mathrm{SE}$.

$\iota, b$, and $c$ indicate significant difference. Significance was considered at $(P \leq 0.05)$

Figure 3: Villus height to crypt depth (V:C) ratio of single OA supplemented groups.

Gr. 1 (formic acid), Gr. 2 (lactic acid), Gr. 3 (propionic acid), Gr. 4 (citric acid).



Figure 4: Photomicrograph showing duodenum of broiler chicken supplemented with OAB; (a) Gr. 5 (Formic + Lactic + propionic), (b) Gr. 6 (Formic + Lactic acid + Citric), (c) Gr. 7 (Formic + Propionic + Citric), (d) Gr. 8 (Lactic + Propionic + Citric), (e) Gr. 9 (control group).
V/C Ratio

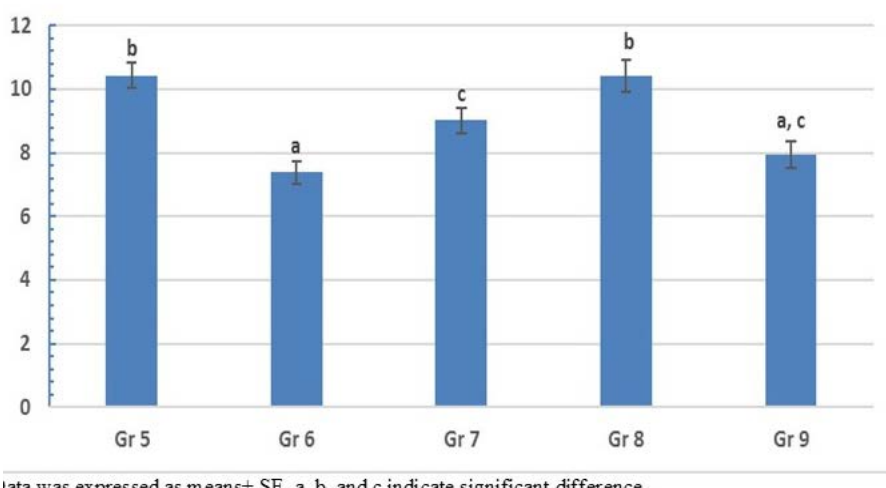

ignificance was considered at $(\mathrm{P} \leq 0.05)$

Figure 5: Villus height to crypt depth (V:C) ratio of OAB supplemented groups.

Gr. 5 (Formic + Lactic + propionic), Gr. 6 (Formic + Lactic acid + Citric), Gr. 7 (Formic + Propionic + Citric), Gr. 8 (Lactic + Propionic + Citric), Gr. 9 (control group).

Previous studies revealed that using of propionic acid in combination with formic acid as a mixture $(0.6 \%)$ has a significant improvement in FCR compared to using propionic acid alone (Venkatasubramani et al., 2014). Likewise, using formic and propionic acid mixture has synergistic effect on the weight gain, FCR and increase nitrogen retention (Desai et al., 2007). In contrast, (Hernández et al., 2006) reported that there was any growth performance effect by using propionic acid in combination with formic.

Our results revealed that using mixture of propionic acid in combination with formic and citric acid $\mathrm{pH}$ (3.7) revealed the highest final body weight $(2566 \mathrm{~g})$ with lowest FCR (1.36) $(\mathrm{P}<0.0001)$ compared to negative control group.

Prolonged usage of acidified water with a mixture of propionic acid, formic and lactic acid) with $\mathrm{pH}$ (3.55) resulted in significant $(\mathrm{P}<0.0001)$ increase in the body weight (2536 g) with (FCR 1.40) compared to negative control group.

Previous studies reported that the body weight can be improved when broilers fed diets containing a mixture of $0.6 \%$ of formic and propionic acids (Khan and Nagra,2010). Meanwhile, (Samanta et al., 2010; Hossain and Nargis, 2016) investigated the effect of dietary supplementation of OA mixture containing formic and propionic acid for 35 days that lead to enhancement in protein digestion and increasing the broiler musculature. In contrast, continuous administration of water acidifiers from hatch to 42 days old had no effect on the body weight and survival rate but can improve the FCR (Marín-Flamand et al., 2013). Our results confirmed that mixing of propionic acid with other organic acids could overcome the unpalatable taste of acid 
alone and has a synergistic effect on improving the body weight and FCR.

Our results indorsed by histopathological examination of previous two blends contain propionic acid with other Organic acids represent high V:C ratio with long villus and insignificant crypt depth. Similar to this result, (Adil et al., 2010) reported that $\mathrm{OAB}$ supplementation in diet markedly increase villus high of all intestinal segment of broiler but crypt depth not affected. (Emami et al., 2017) reported increase of villus high and surface area of absorption causing increase of growth rate when broiler feed mixture of propionic and formic acid. while (Owens et al., 2008) did not observe any significant in intestinal histology of broiler supplemented with $\mathrm{OAB}$.

Previous studies reported that a significant increase in the body weight while using $0.25 \%$ citric acid continuously for 42 days (Wickramasinghe et al., 2014). The improvement of broiler body weight treated with citric acid may be due to improvement in the protein digestion, mineral utilization, and reduction of microbial load in intestinal tract (Chowdhury et al., 2009; Alzawqari et al., 2013). Our results revealed that treated group with citric acid $1 \%$ in drinking water $(\mathrm{pH} 3.7)$ showed a significant $(\mathrm{P}=0.003)$ increase in the final body weight $(2513 \mathrm{~g})$ with low (1.40 FCR).

Continuous usage of acidified water $(\mathrm{pH} 4.5)$ by citric acid has a trophic change in duodenum villi length and crypt depth (Abdelrazek et al., 2016). While another study reported that there is no any effect of OA on the villus height and crypt depth of turkey intestine (Milbradt et al., 2014). Our results showed that good performance achieved by using of citric acid with long villi $(\mathrm{P} \leq 0.05)$ and deep non-significant crypt.

The broiler performance can be improved with using lactic acid 2\% used for 6 weeks continuously (Versteegh and Jongbloed, 1999). Histological examination of lactic acid treated group shown a significant long Villi and nonsignificant crypt depth with highest V:C ratio. (Chaveerach et al., 2004) demonstrated that duodenum epithelial cells were not damaged and improved by using OA as a water supplement. Our results revealed that broiler supplemented with $1 \%$ lactic acid in drinking water $(\mathrm{pH} 2.74)$ lead to non-significant increase in the body weight $(2485 \mathrm{~g})$ with FCR (1.42) $(\mathrm{P}=0.075)$.

Previous findings shown that supplementation with mixture of OAs containing lactic, citric and orthophosphoric acid to the broiler drinking water for 5 weeks was able to increase the body weight even in heat stressed condition (Kammon et al., 2019). Likewise, using lactic, citric and formic acids for 42 day can increase the body weight gain, general performance (Hashemi et al., 2014). Using a mixture of formic, lactic and citric acids $(\mathrm{pH} \mathrm{3.5)}$ in the broiler water has a significant effect on improved the body weight performance $(2523 \mathrm{~g})(\mathrm{P}=0.006)$ and low FCR (1.3). Our results supported by the duodenum histopathological examination that shown a significant high villi with deep crypt depth and non-significant $\mathrm{V}: \mathrm{C}$ ratio which is in agreement with (Hashemi et al., 2014) who found a dramatic change in the villus height and crypt depth with high V:C ratio.

Aadministration of mixture of OAs containing lactic, propionic, formic acids has a positive effect on the growth performance only at the finisher phase (Eftekhari et al., 2015). Also, using of mixture containing lactic acid and propionic salt in water $(\mathrm{pH} 3.9)$ can increase the body weight and improve in flock uniformity through the whole rearing period (Šamudovská et al., 2018). Using acidified water with $1 \%$ concentration of a mixture containing lactic, propionic, and citric acids ( $\mathrm{pH}$ 3.6) has a significant $(\mathrm{P}=0.015)$ in body weight $(2484 \mathrm{~g})$ and low $(1.43 \mathrm{FCR})$ comparing. Our results supported by the duodenum histopathological examination that shown the best mucosal measure as it has long villi with deep crypt to make highest $\mathrm{V}: \mathrm{C}$ ratio.

Using single OA (formic acid 1\%) in drinking water $(\mathrm{pH}$ 2.5) achieved the lowest performance among all treated groups. and shown a significant $(\mathrm{P}<0.0001)$ decrease body weight $(2133 \mathrm{~g})$ with high FCR (1.65). These results are similar to previous findings that reported that long time supplementing of formic acid ( $\mathrm{pH} 4.5$ ) were significantly decrease the body weight at finisher phase (Aclkgoz et al., 2011).

Previous studies revealed that supplementing organic acid in water increased the feed intake in finisher phase (Hossain and Nargis, 2016). Interestingly, our results revealed that acidified water by organic acids can improve the final body weight without increasing the feed intake.

\section{CONCLUSIONS AND RECOMMENDATIONS}

Our findings revealed that water acidification by using OAs either in single (except formic acid) or mixture form for 12 hours per day starting from day 7 old till the end of experiment ( 35 day old) achieved high performance compared to non-treated control group (negative control group). In addition, continuous addition of OAs did not cause any harm to the flock but exerted beneficial effects. The best used single OA was Propionic acid 1\% which reduce the water $\mathrm{pH}$ to 3.2 and achieved high final body weight (2537 g) with low FCR (1.41) and modulating 
the intestinal mucosa (high $\mathrm{V}: \mathrm{C}$ ratio; 10.7). While, using mixture of OAs, our results showed that $1 \%$ of mixture (Formic+ Lactic+ Propionic acid) was the best mixture as it reduced the water $\mathrm{pH}$ to 3.5 and expressed the highest final body weight $(2559 \mathrm{~g})$ and low FCR (1.41) with modulating intestinal mucosal(V:C ratio; 10.4). So, we conclude that the best performance for broilers achieved when the water $\mathrm{pH}$ was ranging from 2.7 to 3.7 and the optimum production can be reached by using acidified water has $\mathrm{pH} 3.2$ (single propionic) and 3.5 (Formict Lactic+ Propionic), respectively.

\section{ACKNOWLEDGMENTS}

The Authors thank MEVAC Facility for Veterinary Vaccines for their product support during experimental trial. The facility supplies us with (Var $2^{\circledR}$ and ME FluVac $H 5^{\oplus}$ ) vaccines and monitor the vaccination process by their technical team.

\section{AUTHORS CONTRIBUTION}

All Authors contribute equally in research artiche. M.M. Ali, Shimaa A.E. Nasr, M.A.H ElShater: put the idea of work \& supervise the work M.M. Hamoud: supply the research with materials as ration and chicks. \& Idea of work. H.M. El Agrab: continues the progress of experiment, Share in idea \& supervise work. Asmaa M. Ali, Dr. A.M. Gamal,M.R. Mousa, and Samah E. Laban : share in practical work of experiment. O.K. Zahran and Asmaa M. Ali writing and revision of article.

\section{CONFLICT OF INTEREST}

The authors have declared no conflict of interest.

\section{FUNDING}

This research was a part of Ph.D. thesis and did not receive any specific grant from funding agencies in the public, commercial, or not-for-profit sectors.

\section{REFERENCES}

-Abdelrazek HMA, Abuzead SMM, Ali aA-F, El-Genaidy HMA, Abdel-Hafez S (2016). Effect of citric and acetic acid water acidification on broiler's performance with respect to thyroid hormones levels. Adv. Anim. Vet. Sci., 4: 271-278. https://doi.org/10.14737/journal.aavs/2016/4.5.271.278

-Aclkgoz Z, Bayraktar H, Altan O (2011). Effects of formic acid administration in the drinking water on performance, intestinal microflora and carcass contamination in male broilers under high ambient temperature. Asian Austral. J. Anim. Sci., 24: 96-102. https://doi.org/10.5713/ ajas.2011.10195
-Adil S, Banday T, Bhat GA, Mir MS, Rehman M (2010). Effect of dietary supplementation of organic acids on performance, intestinal histomorphology, and serum biochemistry of broiler chicken. Vet. Med. Int.,Volume 2010, Article ID 479485, 7 pages. https://doi.org/10.4061/2010/479485

- Alzawqari MH, Kermanshahi H, Moghaddam HN, Tawassoli MH, Gilani A (2013). Alteration of gut microflora through citric acid treated drinking water in preslaughter male broilers. Afr. J. Microbiol. Res., 7: 564-567.

-Araujo R, Polycarpo GV, Barbieri A, Silva KM, Ventura G, Polycarpo VCC (2019). Performance and economic viability of broiler chickens fed with probiotic and organic acids in an attempt to replace growth-promoting antibiotics. Braz. J. Poult. Sci., 21: 001-008. https://doi.org/10.1590/18069061-2018-0912

-Aviagen (2018). arbor acers broiler management handbook. http://eu.aviagen.com/assets/Tech_Center/AA_Broiler/ AA-BroilerHandbook2018-EN.pdf.

- Bancroft JD, Gamble M (2008). Theory and practice of histological techniques, sixth edition. Elsevier Health Sci., pp. 83-121.

- Chaveerach P, Keuzenkamp D, Lipman L, Van Knapen F (2004). Effect of organic acids in drinking water for young broilers on Campylobacter infection, volatile fatty acid production, gut microflora and histological cell changes. Poult. Sci., 83: 330-334. https://doi.org/10.1093/ps/83.3.330

- Chowdhury R, Islam K, Khan M, Karim M, Haque M, Khatun M, Pesti G (2009). Effect of citric acid, avilamycin, and their combination on the performance, tibia ash, and immune status of broilers. Poult. Sci. Symp., 88: 1616-1622. https:// doi.org/10.3382/ps.2009-00119

- Desai D, Patwardhan D, Ranade A (2007). Acidifiers in poultry diets and poultry production. A guide for feed preservation. Acidification to promote animal performance (Ed.C.luckstadt) Nottingham Univ. Press., pp. 63-69. https://doi.org/10.7313/UPO9781904761938.008

-Eftekhari A, Rezaeipour V, Abdullahpour R (2015). Effects of acidified drinking water on performance, carcass, immune response, jejunum morphology, and microbiota activity of broiler chickens fed diets containing graded levels of threonine. Livest. Sci., 180: 158-163. https://doi. org/10.1016/j.livsci.2015.07.010

-Emami NK, Daneshmand A, Naeini SZ, Graystone EN, Broom LJ (2017). Effects of commercial organic acid blends on male broilers challenged with E. coli K88: Performance, microbiology, intestinal morphology, and immune response. Poult. Sci., 96: 3254-3263. https://doi.org/10.3382/ps/ pex106

- Hamid H, Shi H, Ma G, Fan Y, Li W, Zhao L, Zhang J,Ji C, Ma $\mathrm{Q}$ (2018). Influence of acidified drinking water on growth performance and gastrointestinal function of broilers. J. Poult. Sci., 97: 3601-3609. https://doi.org/10.3382/ps/ pey 212

-Hashemi S, Zulkifli I, Davoodi H, Hair Bejo M, Loh T (2014). Intestinal histomorphology changes and serum biochemistry responses of broiler chickens fed herbal plant (Euphorbia hirta) and mix of acidifier. Iran. J. Appl. Anim. Sci., 4: 95103.

- Hernández F, Garcia V, Madrid J, Orengo J, Catalá P, Megias M (2006). Effect of formic acid on performance, digestibility, intestinal histomorphology and plasma metabolite levels of broiler chickens. Br. Poult. Sci., 47: 50-56. https://doi. org/10.1080/00071660500475574 
- Hossain M, Nargis F (2016). Supplementation of organic acid blends in water improves growth, meat yield, dressing parameters and bone development of broilers. Bangladesh J. Anim. Sci., 45: 7-18. https://doi.org/10.3329/bjas. v45i1.27482

-Huyghebaert G, Ducatelle R, Van Immerseel F (2011). An update on alternatives to antimicrobial growth promoters for broilers. Vet. J., 187: 182-188. https://doi.org/10.1016/j. tvj1.2010.03.003

- Kammon A, Alzentani S, Tarhuni O, Asheg A (2019). Research Article Effect of Some Organic Acids on Body Weight, Immunity and Cecal Bacterial Count of Chicken during Heat Stress. Int. J. Poult. Sci., 10.3923/ijps.2019. https://doi. org/10.3923/ijps.2019.293.300

- Khan A, Nagra S (2010). Performance of broiler chicks as influenced by feeding diets supplemented with organic acids. Indian J. Poult. Sci., 45: 30-34.

-Khan SH, Iqbal J (2015). Recent advances in the role of organic acids in poultry nutrition. J. Appl. Anim. Res., 44: 359-369. https://doi.org/10.1080/09712119.2015.1079527

- Kopecký J, Hrnčár C, Weis J (2012). Effect of organic acids supplement on performance of broiler chickens. Anim. Sci. Biotechnol., 45: 51-54.

-Krug PW, Larson CR, Eslami AC, Rodriguez LL (2012). Disinfection of foot-and-mouth disease and African swine fever viruses with citric acid and sodium hypochlorite on birch wood carriers. Vet. Microbiol., 156: 96-101. https:// doi.org/10.1016/j.vetmic.2011.10.032

-Marín-Flamand E, Vázquez-Durán A, Méndez-Albores A (2013). Effect of organic acid blends in drinking water on growth performance, blood constituents and immune response of broiler chickens. J. Poult. Sci., pp. 0120179. https://doi.org/10.2141/jpsa.0120179

- Milbradt E, Okamoto AS, Rodrigues J, Garcia EA, Sanfelice C, Centenaro L, Filho RA (2014). Use of organic acids and competitive exclusion product as an alternative to antibiotic as a growth promoter in the raising of commercial turkeys. Poult. Sci. Symp., 93: 1855-1861. https://doi.org/10.3382/ ps.2013-03593

- Montagne L, Pluske J, Hampson D (2003). A review of interactions between dietary fibre and the intestinal mucosa, and their consequences on digestive health in young nonruminant animals. Anim. Feed sci.Technol. Health Care, 108: 95-117. https://doi.org/10.1016/S0377-8401(03)00163-9

- Nourmohammadi R, Hosseini SM, Farhangfar H, Bashtani M (2012). Effect of citric acid and microbial phytase enzyme on ileal digestibility of some nutrients in broiler chicks fed corn-soybean meal diets. Ital. J. Anim. Sci., 11: e7. https://

\section{doi.org/10.4081/2326}

- Owens B, Tucker L, Collins M, McCracken K (2008). Effects of different feed additives alone or in combination on broiler performance, gut microflora and ileal histology. Br. Poult. Sci., 49: 202-212. https://doi.org/10.1080/00071660802004890

- Paul SK, Halder G, Mondal MK, Samanta G (2007). Effect of organic acid salt on the performance and gut health of broiler chicken. J. Poult. Sci., 44: 389-395. https://doi.org/10.2141/ jpsa.44.389

- Roy P, Dhillon A, Lauerman LH, Schaberg D, Bandli D, Johnson S (2002). Results of Salmonella isolation from poultry products, poultry, poultry environment, and other characteristics. Avian Dis., 46: 17-24. https://doi. org/10.1637/0005-2086(2002)046[0017:ROSIFP]2.0. $\mathrm{CO} ; 2$

- Samanta S, Haldar S, Ghosh TK (2010). Comparative efficacy of an organic acid blend and bacitracin methylene disalicylate as growth promoters in broiler chickens: effects on performance, gut histology, and small intestinal milieu. Vet. Med. Int., Volume 2010, Article ID 645150, 8 pages. https://doi.org/10.4061/2010/645150

- Šamudovská AH, Demeterová M, Skalická M, Bujňák L, Nad’ P (2018). Effect of water acidification on some morphological, digestive and production traits in broiler chickens. Bulg. J. Vet.Med.,21:269-278.https://doi.org/10.15547/bjvm.1065

-Shokryazdan P, Jahromi MF, Liang JB, Ramasamy K, Sieo CC, Ho YW (2017). Effects of a Lactobacillus salivarius mixture on performance, intestinal health and serum lipids of broiler chickens. PLoS One, pp. 12. https://doi.org/10.1371/ journal.pone.0175959

-Van Bunnik B, Katsma W, Wagenaar J, Jacobs-Reitsma W, De Jong M (2012). Acidification of drinking water inhibits indirect transmission, but not direct transmission of Campylobacter between broilers. Prev. Vet. Med., 105: 315319. https://doi.org/10.1016/j.prevetmed.2012.03.007

-Venkatasubramani R, Vasanthakumar P, Chandrasekaran D, Rajendran D, Purushothaman M (2014). Performance of broilers fed formic and propionic acid supplemented diets. Anim. Nutr. Feed Technol., 14: 81-90.

-Versteegh H, Jongbloed A (1999). The effect of supplementary lactic acid in diets on the performance of broilers. ID-DLO Rep.,

-Wickramasinghe K, Atapattu N, Seresinhe R (2014). Effects of citric acid on growth performance and nutrient retention of broiler chicken fed diets having two levels of non-phytate phosphorus and rice Bran. Iran. J. Appl. Anim. Sci., 4: 809815 